\title{
The Bear River dykes (1265-1269 Ma): westward continuation of the Mackenzie dyke swarm into Yukon, Canada
}

\author{
Danette L. Schwab ${ }^{\mathrm{a}, *}$, Derek J. Thorkelson ${ }^{\text {a }}$, James K. Mortensen ${ }^{\mathrm{b}}$, \\ Robert A. Creaser ${ }^{\mathrm{c}}$, J. Grant Abbott ${ }^{\mathrm{d}}$ \\ a Department of Earth Sciences, Simon Fraser University, Burnaby, BC, Canada V5A 1S6 \\ ${ }^{\mathrm{b}}$ Department of Earth and Ocean Sciences, University of British Columbia, Vancouver, BC, Canada V6T 2B4 \\ ${ }^{\mathrm{c}}$ Department of Earth and Atmospheric Sciences, University of Alberta, Edmonton, Alta., Canada, T6G 2E3 \\ d Yukon Geology Program, Whitehorse, Yukon, Canada Y1A 2 C6
}

Received 30 July 2003; accepted 6 April 2004

\begin{abstract}
The 1.27 Ga Mackenzie dyke swarm, the largest on Earth, radiates from a point in the western Canadian Arctic and extends across much of the Canadian Shield. Possible western extensions of the swarm are largely obscured by younger sedimentary cover. Paleoproterozoic inliers in northern Yukon host the Bear River dykes (BRD), herein dated by U-Pb baddeleyite and zircon methods at $1268.5 \pm 1.5 \mathrm{Ma}$ and $1264.6 \pm 1.2 \mathrm{Ma}$. The BRD share similar geochemical and Nd-isotopic characteristics with the Mackenzie dykes and the coeval Coppermine River basalts, and are regarded as products of the same plume. Hydrothermal activity at $\sim 1270 \mathrm{Ma}$ in breccia of the Nor mineral occurrence, northwest of the BRD, was probably generated by BRD at depth. The BRD generally strike northwest, approximately $90^{\circ}$ to the orientation predicted by the radiating dyke model. This difference may be explained by an anomalous local stress field at the time of BRD emplacement, or reorientation of BRD during subsequent events of Cordilleran deformation. Using the Nor mineral occurrence as the westernmost locale of Mackenzie dyking, and assuming a model of uniform dyke radiation, the arc of the Mackenzie swarm is at least $50^{\circ}$ greater than previously recognized, bringing the total arc of dyke radiation to $>150^{\circ}$.
\end{abstract}

(C) 2004 Elsevier B.V. All rights reserved.

Keywords: Dyke; Cordillera; Yukon; Mantle plume; Proterozoic; Mackenzie

\section{Introduction}

Radiating mafic dyke swarms represent brief but voluminous injections of mantle-derived magma into

\footnotetext{
* Corresponding author. Present address: SRK Consulting, 800-1066 W. Hastings St., Vancouver, BC, Canada V6E 3X2. Tel.: +1 604601 8429; fax: +1 6046875532 .

E-mail addresses: dschwab@srk.com (D.L. Schwab), dthorkel@sfu.ca (D.J. Thorkelson), jmortens@eos.ubc.ca (J.K. Mortensen), robert.creaser@ualberta.ca (R.A. Creaser), grant.abbott@gov.yk.ca (J.G. Abbott).
}

dilatant crust. Many are linked to continental flood basalts, and are attributed to the arrival of a mantle plume head (Campbell and Griffiths, 1990; Ernst et al., 1995a) or a magmatic outburst above a steady-state hotspot (Johnston and Thorkelson, 2000). Anomalously high mantle temperatures and huge volumes of uprising melt, leading to updoming of the crust and outflow of magma from the hot-spot, are the most likely causes of the radiating dyke patterns.

The Mackenzie dyke swarm is the largest swarm on Earth, radiating with an arc of $\sim 100^{\circ}$ across most of the Canadian Shield (Fahrig and West, 1986; Ernst 


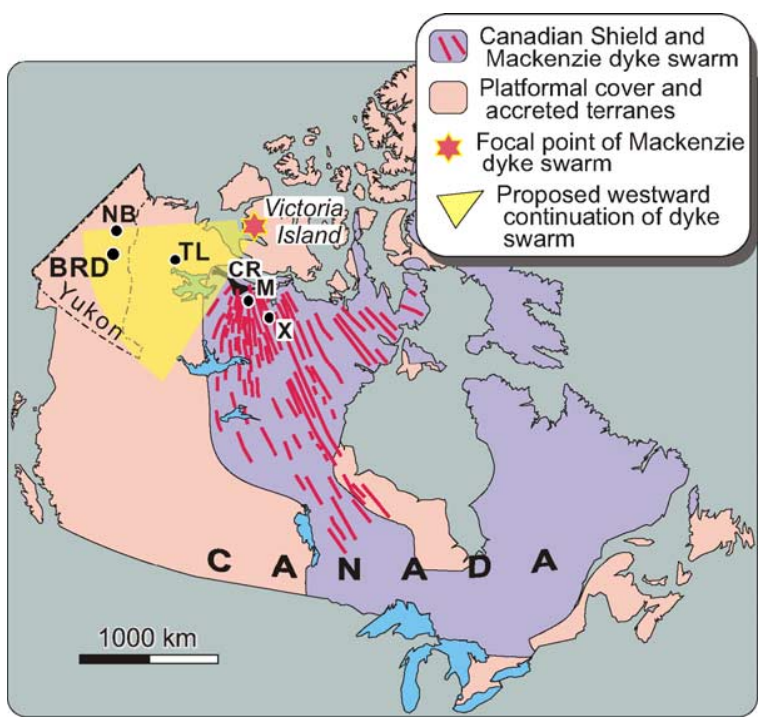

Fig. 1. Map of Canada showing main features of the Mackenzie igneous event (after Fahrig and West, 1986; Hoffman, 1989; LeCheminant and Heaman, 1989; Ernst and Baragar, 1992). Yellow fan-shaped area represents proposed, mainly subsurface continuation of the Mackenzie dyke swarm into western Canada. Canadian Shield is mainly Middle Proterozoic to Archean; Platformal cover and accreted terranes is mainly Late Proterozoic and Phanerozoic. BRD: Bear River dykes; CR: Coppermine River Group basalts (black area); M: Muskox intrusion; NB: Nor breccia; TL: Tweed Lake basalts (subsurface); X: xenolith locality of Davis (1997).

et al., 1995a). It fans from a focal point on Victoria Island, near the Arctic coast, and extends eastward for $\sim 1400 \mathrm{~km}$ to the eastern Canadian Arctic, and southward for $\sim 2400 \mathrm{~km}$ into northwestern Ontario (Fig. 1). The dykes were emplaced in the same event that led to eruption of the Coppermine River flood basalts, the Tweed Lake basalts (preserved in the subsurface $\sim 250 \mathrm{~km}$ to the west; Sevigny et al., 1991), and emplacement of the Muskox layered intrusion (Baragar, 1969; Dostal et al., 1983; LeCheminant and Heaman, 1989; Francis, 1994). All of the igneous activity is considered to have occurred within a few million years of $1267 \mathrm{Ma}$ (LeCheminant and Heaman, 1989). The large volume of magma, the radial flow pattern, and the inferred short time span of emplacement point to a mantle plume origin (LeCheminant and Heaman, 1989; Ernst and Baragar, 1992; Ernst et al., 1995a).

In this paper we examine the field relations, age, and geochemistry of the mafic Bear River dykes (BRD) which are exposed in an Early Proterozoic inlier of northern Yukon (Fig. 2). The inlier is separated from the Mackenzie dyke swarm by a 700-km wide swath of Middle Proterozoic to Phanerozoic sedimentary cover (Fig. 1), nearly all of which was deposited after ca. $1.27 \mathrm{Ga}$ Mackenzie magmatism. We characterize the BRD using petrography, major and trace element geochemistry, $\mathrm{Nd}$ isotopes, and $\mathrm{U}-\mathrm{Pb}$ geochronology, and propose a correlation with the Mackenzie dykes. Relations with the $1.27 \mathrm{Ga}$ Nor hydrothermal breccia of northeastern Yukon are explored, and an increase in the estimated size of the Mackenzie dyke swarm is corroborated.

\section{Bear River dykes}

The BRD occur in a Proterozoic inlier in northern Yukon (Fig. 2), where they crosscut Early Proterozoic sedimentary strata of the Wernecke Supergroup (Thorkelson, 2000). One of the dykes was mapped by Blusson (1974), who assigned it a provisional Cretaceous age. Subsequent work including comprehensive studies by Abbott (1997) and Thorkelson (2000) have not revealed any Cretaceous-aged dykes in the Proterozoic inliers, and the assignment by Blusson (1974) is considered to be incorrect. Thorkelson (2000) and Schwab and Thorkelson (2001) identified about 15 dykes in at least seven localities (simplified in Fig. 2). Some of the dykes are present as individual intrusions, whereas others occur in swarms of up to 8 dykes. The dykes are $5-15 \mathrm{~m}$ thick and up to $5 \mathrm{~km}$ long (Figs. 2 and 3). They are subvertical, and strike mainly to the northwest. They consist of medium to fine grained diorite and gabbro, variably altered to lower greenschist metamorphic grades. Mineralogy is dominated by subequal amounts of clinopyroxene and plagioclase, with accessory magnetite, apatite, interstitial granophyre, and local late-stage biotite. Plagioclase is variably altered to clay, mica, calcite, chlorite and epidote; clinopyroxene is commonly pseudomorphed by chlorite. One of the dykes (dyke 1 in Fig. 2) is crosscut by undated hematitic veins and is metasomatically enriched in $\mathrm{Cu}$ and $\mathrm{U}$ (Schwab and Thorkelson, 2001). Another dyke (dyke 3) contains a weak penetrative foliation of unknown age and origin. Despite these minor variations in fabric and alteration, the BRD have consistent compositions, orientations and dimensions, and are considered part of a single magmatic event. 


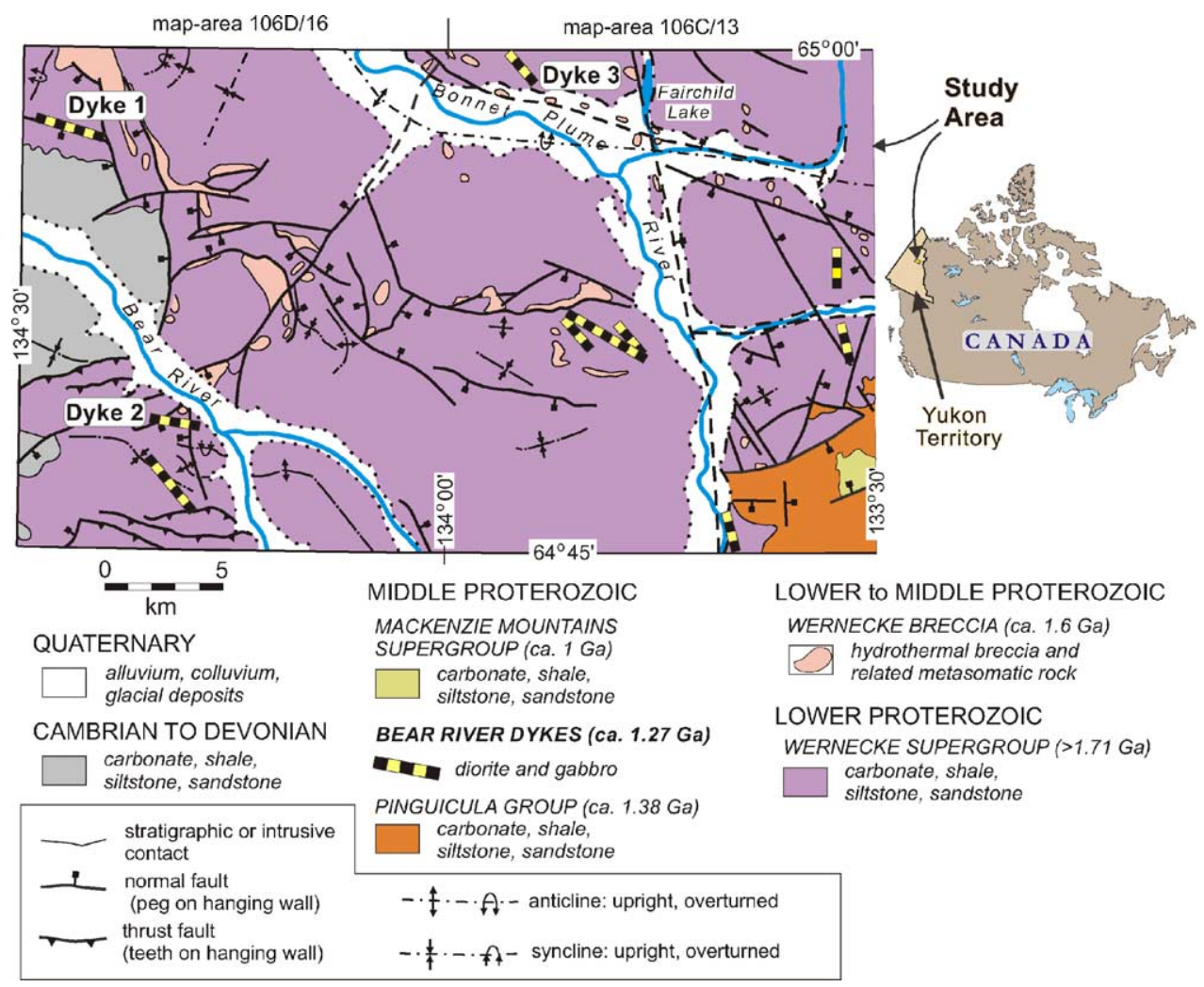

Fig. 2. Simplified geological map of the study area (map areas 106 D/16, 106 C/13) showing locations of the Bear River dykes (simplified from Thorkelson, 2000). Dykes 1, 2, and 3 are dated by U-Pb geochronology (this paper).



Fig. 3. Bear River dyke crosscutting steeply dipping, previously folded dolostone of the Wernecke Supergroup. Dyke is located in southwestern corner of Fig. 2, south of dyke 2. Dolostone in contact with dyke has been metamorphosed to white-weathering calcite marble. Dyke is approximately $15 \mathrm{~m}$ wide and dips away from viewer at $75^{\circ}$.
Details on age and geochemistry, provided below, support this suggestion.

\subsection{Regional geology}

The BRD intruded a complex Proterozoic orogen that developed over a preceding interval of at least 450 million years As shown in Figs. 2 and 4, the oldest exposed rocks are the Wernecke Supergroup, a 13-km thick succession of fine-grained basinal siliciclastic rocks and platformal carbonates which were deposited on a basement of unknown age and affinity. The Wernecke Supergroup was deformed and metamorphosed during three phases of deformation, collectively termed the Racklan orogeny (Brideau et al., 2002), intruded by the $1.71 \mathrm{Ga}$ rift-related Bonnet Plume River Intrusions (Thorkelson et al., 2001a), and crosscut by the $1.60 \mathrm{Ga}$ Wernecke Breccias, of hydrothermal origin (Thorkelson et al., 2001b). The 


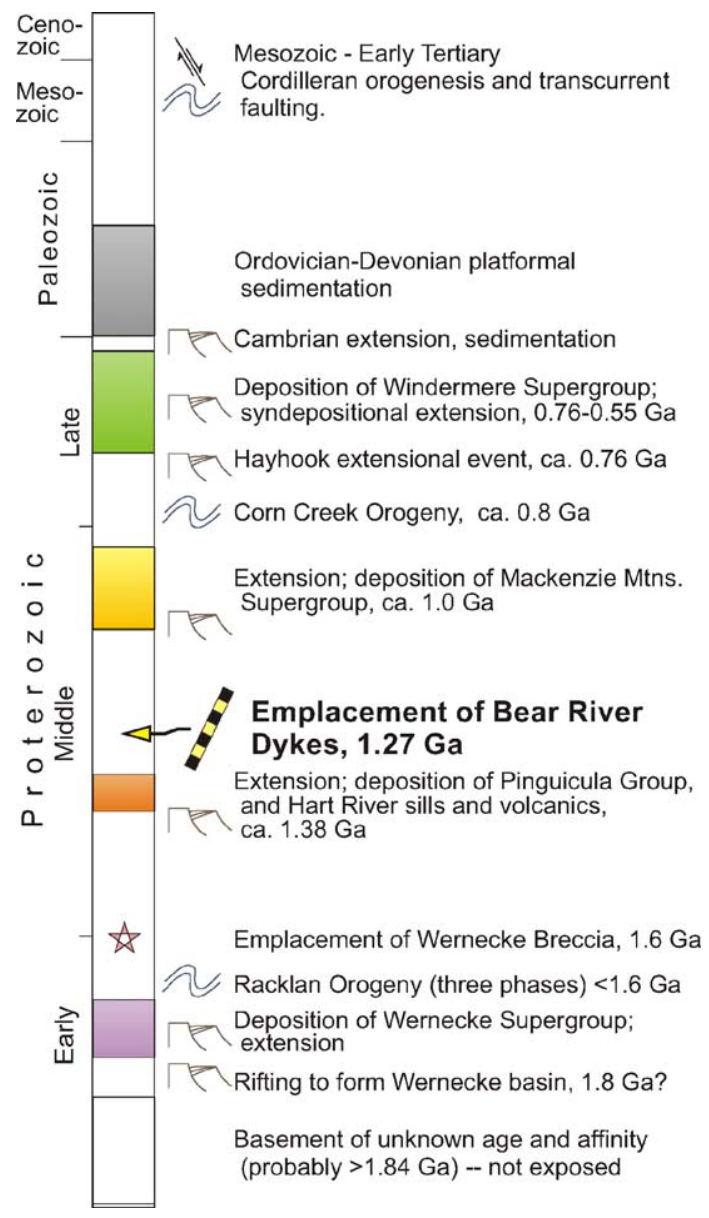

Fig. 4. Time-stratigraphic column for the study area (Fig. 2) and adjacent areas, showing Bear River dykes in context of geological evolution of northern Yukon (modified from Thorkelson, 2000). Note at least five events of extension, two events of contraction, and one event of strike-slip deformation following emplacement of Bear River dykes.

region was subsequently extended, intruded by the Hart River mafic sills, and overlain by the mafic Hart River volcanics and the clastic-carbonate Pinguicula Group. As indicated in Fig. 4, the BRD intruded the area following Pinguicula Group sedimentation, although all of the BRD identified so far are hosted by the Wernecke Supergroup, and none have yet been observed to crosscut the Pinguicula Group.

After emplacement of the BRD, the region underwent at least four events of extension leading to deposition of the Mackenzie Mountains Supergroup (Aitken et al., 1982; Norris and Dyke, 1997), the Win- dermere Supergroup (Eisbacher, 1981), and Paleozoic platformal strata (Cecile, 1982). West-verging folding and thrust-faulting occurred in the Middle Proterozoic between deposition of the Pinguicula and Mackenzie Mountains successions (Eisbacher, 1981; Thorkelson, 2000). North-verging folding and thrusting, and dextral strike-slip faulting (Cecile, 1984; Abbott, 1997), occurred during Late Cretaceous to Paleogene orogenesis, which affected most of the North American Cordillera (Norris, 1997). Thus, the crust in the study area (Fig. 2) remained mobile for nearly 1.3 billion years after intrusion by the BRD.

Selected folds and faults are illustrated in Fig. 2. Because of the reconnaissance nature of the geological mapping and investigations in the area thus far, many of these structures are poorly constrained in age, and their origins are uncertain. Some older structures have been reactivated or superposed by subsequent events (Thorkelson, 2000), complicating the structural evolution. Nevertheless, the history depicted in Fig. 4 is supported by observations in key localities and provides a rationale for the possible structural reorientation of the BRD, as considered below.

\subsection{Geochemistry}

Geochemical analyses were obtained by X-ray fluorescence and inductively coupled mass spectrometry for seven samples of the BRD from five of the six dyke localities. $\mathrm{Nd}$ isotopic data were obtained for four of the least-altered samples at the University of Alberta. All of the data are reported in Table 1. Mobility of the large-ion lithophile elements (LILE), such as K, $\mathrm{Rb}, \mathrm{Cs}, \mathrm{U}$ and $\mathrm{Th}$, is evident from their large, incoherent variations in abundance. In contrast, the rare earth elements (REE) and high field strength elements (HFSE) show less scatter and yield consistent patterns on multi-element diagrams (Fig. 5).

The BRD are evolved quartz tholeiites with magnesium numbers ranging from 42 to 59 (Table 1). The range of $\mathrm{Cr}$ concentrations (109-409 ppm), and a trend toward iron enrichment (Schwab, 2001), also indicate evolved rather than primary character. Subalkaline composition is inferred by the ubiquity of interstitial quartz. Mantle-normalized trace element profiles (Fig. 5) and chondrite-normalized REE patterns (Schwab, 2001) resemble those of continental flood basalts (e.g., Saunders et al., 1992). BRD patterns 
Table 1

Major and trace element geochemistry, and $\mathrm{Nd}$ isotope composition of the BRD Major oxide, trace element and $\mathrm{Nd}$ isotope data for the Bear River dykes

\begin{tabular}{|c|c|c|c|c|c|c|c|c|}
\hline \multirow{4}{*}{$\begin{array}{l}\text { Sample ID } \\
\text { Location }\end{array}$} & & TOA-96-6-7-2B & DT-96-1-1-1B & DT-92-11-1B & CW-93-19-1B & DT-93-72-1B & DS-00-2-2-8B & DS-00-3-2-5B \\
\hline & NTS & $106 \mathrm{D} / 16$ & $106 \mathrm{C} / 13$ & $106 \mathrm{D} / 16$ & $106 \mathrm{C} / 13$ & $106 \mathrm{C} / 13$ & $106 \mathrm{D} / 16$ & $106 \mathrm{D} / 16$ \\
\hline & UTM E & 527600 & 563700 & 532000 & 556900 & 569600 & 528500 & 527500 \\
\hline & UTM N & 7203300 & 7181700 & 7186800 & 7192900 & 7196900 & 7203000 & 7203500 \\
\hline \multirow{10}{*}{$\begin{array}{l}\text { Major oxides } \\
\quad(\text { wt.\%) }\end{array}$} & $\mathrm{SiO}_{2}$ & 54.34 & 51.80 & 53.53 & 48.81 & 51.92 & 55.59 & 55.70 \\
\hline & $\mathrm{TiO}_{2}$ & 1.05 & 2.29 & 1.09 & 1.30 & 2.28 & 1.18 & 1.15 \\
\hline & $\mathrm{Al}_{2} \mathrm{O}_{3}$ & 14.23 & 11.97 & 13.44 & 12.71 & 13.08 & 14.00 & 14.52 \\
\hline & $\mathrm{FeO}^{*}$ & 10.7 & 14.9 & 11.4 & 17.0 & 14.0 & 12.12 & 10.54 \\
\hline & $\mathrm{MnO}$ & 0.20 & 0.31 & 0.15 & 0.16 & 0.23 & 0.21 & 0.20 \\
\hline & $\mathrm{MgO}$ & 7.20 & 6.93 & 8.05 & 6.19 & 5.89 & 6.67 & 5.83 \\
\hline & $\mathrm{CaO}$ & 7.83 & 6.73 & 6.74 & 9.48 & 8.34 & 6.50 & 7.85 \\
\hline & $\mathrm{Na}_{2} \mathrm{O}$ & 2.17 & 3.86 & 2.21 & 1.61 & 2.91 & 2.23 & 2.55 \\
\hline & $\mathrm{K}_{2} \mathrm{O}$ & 2.16 & 0.99 & 3.24 & 2.65 & 1.11 & 1.36 & 1.52 \\
\hline & $\mathrm{P}_{2} \mathrm{O}_{5}$ & 0.11 & 0.21 & 0.12 & 0.14 & 0.23 & 0.13 & 0.12 \\
\hline \multirow{39}{*}{$\begin{array}{l}\text { Trace elements } \\
\quad(\mathrm{ppm})\end{array}$} & $\mathrm{Ba}$ & 386.75 & 238.33 & 267.85 & 430.71 & 331.84 & 239.87 & 322.52 \\
\hline & $\mathrm{Rb}$ & 76.02 & 24.24 & 164.65 & 35.31 & 25.19 & 32.73 & 41.41 \\
\hline & Cs & 1.89 & 0.86 & 5.72 & 0.90 & 2.57 & N.D. & N.D. \\
\hline & Th & 4.08 & 1.75 & 2.81 & 4.36 & 1.81 & 4.26 & 6.26 \\
\hline & $\mathrm{Ta}$ & 0.47 & 0.54 & 0.52 & 1.09 & 0.59 & N.D. & N.D. \\
\hline & $\mathrm{U}$ & 0.87 & 0.49 & 0.68 & 1.93 & 1.04 & 2.81 & 3.07 \\
\hline & $\mathrm{K}$ & 17952 & 8258 & 26921 & 21989 & 9222 & 11271 & 12656 \\
\hline & $\mathrm{Nb}$ & 7.70 & 9.53 & 6.44 & 15.01 & 10.30 & 8.00 & 9.13 \\
\hline & $\mathrm{La}$ & 15.8 & 11.8 & 13.0 & 21.9 & 12.5 & N.D. & N.D. \\
\hline & $\mathrm{Ce}$ & 32.7 & 29.8 & 27.3 & 49.3 & 31.6 & 53.4 & 24.2 \\
\hline & $\mathrm{Pb}$ & 5.00 & -5.00 & 21.69 & 15.73 & 22.94 & 7.36 & -3.59 \\
\hline & $\mathrm{Sr}$ & 145.5 & 122.6 & 102.9 & 294.5 & 256.0 & 93.7 & 157.5 \\
\hline & $\operatorname{Pr}$ & 3.34 & 3.40 & 3.25 & 5.95 & 4.42 & N.D. & N.D. \\
\hline & $\mathrm{Nd}$ & 15.34 & 17.37 & 13.79 & 22.26 & 20.19 & N.D. & N.D. \\
\hline & $\mathrm{P}$ & 494 & 913 & 503 & 592 & 996 & N.D. & N.D. \\
\hline & $\mathrm{Zr}$ & 100 & 122 & 73 & 113 & 137 & 105 & 118 \\
\hline & $\mathrm{Sm}$ & 3.47 & 4.85 & 3.15 & 4.77 & 5.28 & N.D. & N.D. \\
\hline & $\mathrm{Hf}$ & 2.94 & 3.77 & 2.22 & 3.55 & 3.82 & N.D. & N.D. \\
\hline & $\mathrm{Eu}$ & 1.09 & 1.86 & 0.96 & 1.43 & 1.84 & N.D. & N.D. \\
\hline & Gd & 3.80 & 5.10 & 3.50 & 4.78 & 6.18 & N.D. & N.D. \\
\hline & $\mathrm{Ti}$ & 6303 & 13761 & 6550 & 7802 & 13706 & 5934 & 5537 \\
\hline & $\mathrm{Tb}$ & 0.66 & 0.80 & 0.50 & 0.71 & 0.86 & N.D. & N.D. \\
\hline & Dy & 3.69 & 4.84 & 3.36 & 4.26 & 5.23 & N.D. & N.D. \\
\hline & Ho & 0.72 & 0.89 & 0.62 & 0.84 & 0.97 & N.D. & N.D. \\
\hline & $\mathrm{Er}$ & 2.20 & 2.53 & 1.86 & 2.20 & 2.58 & N.D. & N.D. \\
\hline & $\mathrm{Tm}$ & 0.29 & 0.35 & 0.25 & 0.31 & 0.37 & N.D. & N.D. \\
\hline & $\mathrm{Y}$ & 21.0 & 25.0 & 15.5 & 19.2 & 23.4 & 17.7 & 21.0 \\
\hline & $\mathrm{Yb}$ & 2.15 & 2.26 & 1.63 & 2.04 & 2.05 & N.D. & N.D. \\
\hline & $\mathrm{Lu}$ & 0.32 & 0.32 & 0.24 & 0.29 & 0.29 & N.D. & N.D. \\
\hline & $\mathrm{V}$ & 263 & 369 & 284 & 238 & 419 & 292 & 285 \\
\hline & $\mathrm{Sc}$ & N.D. & N.D. & 31.3 & 25.8 & 28.2 & 29.0 & 25.6 \\
\hline & $\mathrm{Cr}$ & 357 & 129 & 479 & 208 & 109 & 331 & 289 \\
\hline & Co & 69.8 & 69.9 & 41.5 & 33.8 & 45.6 & N.D. & N.D. \\
\hline & $\mathrm{Ni}$ & 162 & 678 & 151 & 82 & 78 & 84 & 87 \\
\hline & $\mathrm{Ga}$ & N.D. & N.D. & N.D. & N.D. & N.D. & 16.22 & 18.76 \\
\hline & $\mathrm{Cu}$ & 122 & 354 & 142 & 70 & 371 & 167 & 101 \\
\hline & $\mathrm{Zn}$ & 50.0 & 267.0 & 102.0 & 120.6 & 156.4 & 30.4 & 15.7 \\
\hline & $\mathrm{Be}$ & N.D. & N.D. & 0.54 & 0.54 & 1.50 & N.D. & N.D. \\
\hline & $\mathrm{Li}$ & N.D. & N.D. & 32.06 & 27.33 & 17.36 & N.D. & N.D. \\
\hline
\end{tabular}


Table 1 (Continued)

\begin{tabular}{|c|c|c|c|c|c|c|c|c|}
\hline \multirow{4}{*}{$\begin{array}{l}\text { Sample ID } \\
\text { Location }\end{array}$} & & TOA-96-6-7-2B & DT-96-1-1-1B & DT-92-11-1B & CW-93-19-1B & DT-93-72-1B & DS- $00-2-2-8 B$ & DS- $00-3-2-5 B$ \\
\hline & NTS & $106 \mathrm{D} / 16$ & $106 \mathrm{C} / 13$ & $106 \mathrm{D} / 16$ & $106 \mathrm{C} / 13$ & $106 \mathrm{C} / 13$ & $106 \mathrm{D} / 16$ & $106 \mathrm{D} / 16$ \\
\hline & UTM E & 527600 & 563700 & 532000 & 556900 & 569600 & 528500 & 527500 \\
\hline & UTM N & 7203300 & 7181700 & 7186800 & 7192900 & 7196900 & 7203000 & 7203500 \\
\hline & $\mathrm{Tl}$ & 0.35 & 1.05 & 0.62 & 0.30 & 0.19 & N.D. & N.D. \\
\hline & $\mathrm{Bi}$ & 0.81 & 0.17 & 0.26 & 0.05 & 0.05 & N.D. & N.D. \\
\hline & $\mathrm{Ag}$ & -0.50 & -0.50 & 0.66 & 1.44 & 0.95 & N.D. & N.D. \\
\hline & $\mathrm{Sn}$ & 0.80 & 1.10 & 35.58 & 1.95 & 1.66 & N.D. & N.D. \\
\hline & $\mathrm{Sb}$ & 2.09 & 2.58 & 7.39 & 2.40 & 1.19 & N.D. & N.D. \\
\hline & $\mathrm{Mn}$ & 1517 & 2435 & 1139 & 1203 & 1770 & N.D. & N.D. \\
\hline$T_{\mathrm{DM}}^{\mathrm{Nd}}(\mathrm{Ga})$ & & 2.72 & N.D. & 2.69 & 2.09 & 2.13 & N.D. & N.D. \\
\hline $\begin{array}{l}\varepsilon_{\mathrm{Nd}(T)} \\
\quad(T=1.27 \mathrm{Ga})\end{array}$ & & -7.2 & N.D. & -5.9 & -1.9 & 1.4 & N.D. & N.D. \\
\hline Mg\# & & 58 & 49 & 59 & 42 & 46 & 53 & 53 \\
\hline
\end{tabular}

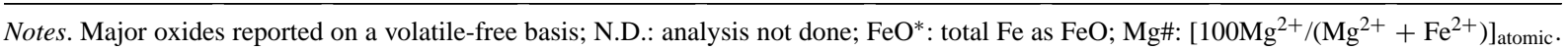

show enrichments of LILE and the light REE, relative to the heavy REE, with chondrite-normalized $\mathrm{Ce} / \mathrm{Yb}$ ranging from 3.4 to 6.1. Relative depletions of $\mathrm{Ta}, \mathrm{Nb}$, $\mathrm{Sr}$ and $\mathrm{P}$, and a slight depletion in $\mathrm{Ti}$, are also persistent features. $\mathrm{La} / \mathrm{Nb}$ ratios range from 1 to 2 , similar to those of modern mid-ocean ridge basalts (Schwab, 2001).

Modeling of closed-system crystal fractionation in the BRD was unsuccessful using mass-balance of ma-

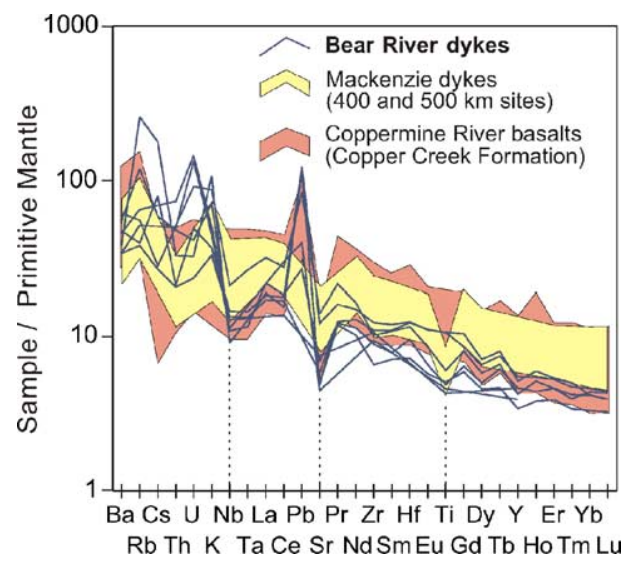

Fig. 5. Trace element profiles of Bear River dykes, showing similarities to Mackenzie dykes at distances of $400-500 \mathrm{~km}$ from focal point (Fig. 1) and the lower lavas of the Coppermine River basalts (Copper Creek Formation). Data sources: Bear River dykes: Thorkelson (2000), Schwab and Thorkelson (2001) (Table 1); Coppermine River basalts: Dupuy and Dostal (1992), Baragar et al. (1996), Griselin et al. (1997); Mackenzie dykes: Gibson et al. (1987), Baragar et al. (1996). Normalizing values from Sun and McDonough (1989). jor oxides and partitioning of trace elements. Fractionation of augite is suggested by the covariation of $\mathrm{Cr}$ and $\mathrm{Sc}$, which are relatively insensitive to crustal assimilation, but modeling of major oxides could not reproduce this finding (Schwab, 2001). Fractionation of plagioclase, the other main mineral phase, is not indicated by either trace or major element systematics and is contra-indicated by a negative correlation between $\mathrm{Sr}$ and magnesium number (Schwab, 2001). The overall chemical variability of the BRD requires open-system processes such as assimilation, mixing of magma, and/or variable mantle sources.

The possibility of crustal contamination and/or variable source characteristics is highlighted by values of $\varepsilon_{\mathrm{Nd}(T)}(T=1.27 \mathrm{Ga})$ which range from +1.4 to -7.2 in four of the BRD (Table 1). If crustal contamination were evoked, this range in values could represent variable degrees of assimilation of old, evolved continental crust by more juvenile, mantle-derived magmas. However, assimilation of evolved crust cannot have been the main process involved, because the $\varepsilon_{\mathrm{Nd}(T)}$ values correlate negatively with $\mathrm{Mg}$-number, $\mathrm{Cr}$, and $\mathrm{Ni}$, and positively with incompatible elements such as the REE (example using $\mathrm{Gd}$ and $\mathrm{Cr}$ shown in Fig. 6). If crustal contamination were prevalent, these trends would imply that the geochemically more primitive dykes (with higher Mg-numbers) had undergone more crustal contamination than the more evolved dykes, the reverse of that expected. To account for these trends, derivation from two mantle sources with contrasting compositions is suggested. One of the mantle sources may have been the asthenosphere, with positive $\varepsilon_{\mathrm{Nd}}$ and a 




Fig. 6. Variations in $\mathrm{Cr}$ and $\mathrm{Gd}$ with increasing $\varepsilon_{\mathrm{Nd}(T)}$, showing regression lines (data from Bear River dykes in study area, Fig. 2, Table 1).

depleted geochemical composition, and the other may have been enriched peridotite with negative $\varepsilon_{\mathrm{Nd}}$, from either the plume or lithospheric mantle reservoirs.

\section{3. $U-P b$ geochronology}

$\mathrm{U}-\mathrm{Pb}$ geochronology was carried out on three samples of fine- to medium-grained BRD. Two of the dykes yielded baddeleyite and one yielded zircon. The samples were dated using conventional U-Pb methods at the Pacific Centre for Isotopic and Geochemical Research at the University of British Columbia. The methodology for sample selection, dissolution, geochemical preparation and mass spectrometry is described in Mortensen et al. (1995). Procedural blanks were $2-5 \mathrm{pg}$ for $\mathrm{Pb}$ and $1 \mathrm{pg}$ for $\mathrm{U}$. $\mathrm{U}-\mathrm{Pb}$ data is presented in Table 2 and are shown on conventional $\mathrm{U}-\mathrm{Pb}$ concordia plots in Fig. 7. Errors are given at the $2 \sigma$ level.

Baddeleyite recovered from dykes 1 and 2 consisted of very fine-grained ( $<62 \mu \mathrm{m}$ maximum dimension), pale to medium brown needles and tabular cleavage fragments. The grains were too fine to permit abrasion prior to dissolution; however they appeared to be inclusion-free and unaltered, with no evidence of secondary alteration to zircon. An initial 20-kg sample collected in 1996 from dyke 1 (Fig. 2) yielded enough baddeleyite for four fractions, and resampling of the same outcrop in 2000 provided enough for an additional two analyses. Despite the apparently unaltered nature of the baddeleyite, all fractions analyzed show evidence of $\mathrm{Pb}$-loss. The six baddeleyite fractions from this dyke outcrop (fractions A1-A6) range from 1.4 to
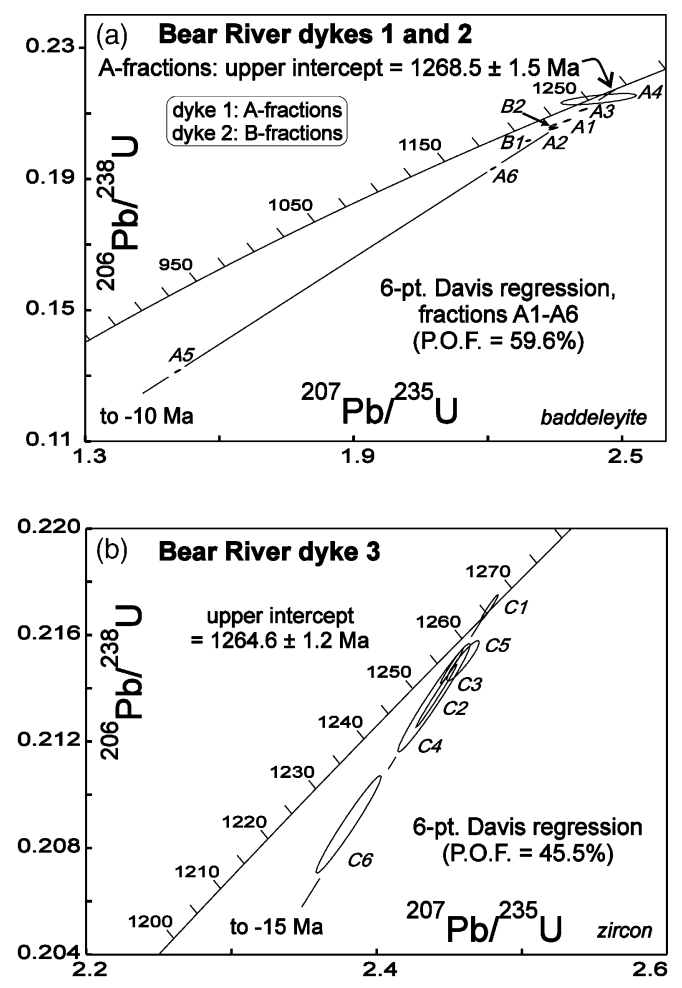

Fig. 7. U-Pb concordia diagram for samples from the Bear River dykes. (a) Dykes 1 and 2, where fractions A1 to A6 are baddeleyite from dyke 1, and fractions $\mathrm{B} 1$ and $\mathrm{B} 2$ are baddeleyite from dyke 2. (b) Dyke 3, zircon fractions $\mathrm{C} 1$ to C6. Errors are at the $2 \sigma$ level. See Fig. 2 for locations.

39.3\% discordant (Fig. 7a), and a Davis-type regression yields calculated upper and lower intercepts of $1268.5 \pm 1.5 \mathrm{Ma}$ and $-10 \mathrm{Ma}$, with a probability of fit of 59.6\%. The upper intercept is interpreted to give the crystallization age of the sample. The near-zero lower intercept is typical for discordant baddeleyite data arrays, as observed by Heaman (1997) and is interpreted as recent $\mathrm{Pb}$-loss. Two fractions of baddeleyite (B1-B2) from dyke 2 (Fig. 2) are both discordant (Fig. 7a), however a regression through the two points yields a similar, although imprecise, upper intercept age of $1265+20 /-11 \mathrm{Ma}$ and a lower intercept of $\sim 221 \mathrm{Ma}$, indicating that this dyke is similar in age to that of dyke 1.

Zircon rather than baddeleyite was recovered from dyke 3 (Fig. 2). The zircon consists of clear, pale brown, stubby to elongate prismatic grains with vague internal zoning and no visible cores. A total of six 
Table 2

$\mathrm{U}-\mathrm{Pb}$ isotope data on zircon and baddeleyite from dykes 1 to 3 of the BRD U-Pb analytical data

\begin{tabular}{|c|c|c|c|c|c|c|c|c|c|c|c|}
\hline $\begin{array}{l}\text { Sample } \\
\text { description }^{\text {a }}\end{array}$ & $\begin{array}{l}\text { Weight } \\
(\mathrm{mg})\end{array}$ & $\begin{array}{l}\text { U content } \\
(\mathrm{ppm})\end{array}$ & $\begin{array}{l}\mathrm{Pb}^{\mathrm{b}} \\
\text { content } \\
(\mathrm{ppm})\end{array}$ & $\begin{array}{l}{ }^{206} \mathrm{~Pb} /{ }^{204} \mathrm{~Pb} \\
(\text { meas. })^{\mathrm{c}}\end{array}$ & $\begin{array}{l}\text { Total } \\
\text { common } \\
\mathrm{Pb}(\mathrm{pg})\end{array}$ & $\%^{208} \mathrm{~Pb}^{\mathrm{c}}$ & $\begin{array}{l}{ }^{206} \mathrm{~Pb} /{ }^{238} \mathrm{U}^{\mathrm{d}} \\
( \pm 1 \%)\end{array}$ & $\begin{array}{l}{ }^{207} \mathrm{~Pb} /{ }^{235} \mathrm{U}^{\mathrm{d}} \\
( \pm 1 \%)\end{array}$ & $\begin{array}{l}{ }^{207} \mathrm{~Pb} /{ }^{206} \mathrm{~Pb}^{\mathrm{d}} \\
( \pm 1 \%)\end{array}$ & $\begin{array}{l}{ }^{206} \mathrm{~Pb} /{ }^{238} \mathrm{U} \\
\mathrm{age}^{\mathrm{e}} \\
(\mathrm{Ma} ; \pm 2 \%)\end{array}$ & $\begin{array}{l}{ }^{207} \mathrm{~Pb} /{ }^{206} \mathrm{~Pb} \\
\mathrm{age}^{\mathrm{e}} \\
(\mathrm{Ma} ; \pm 2 \%)\end{array}$ \\
\hline \multicolumn{12}{|c|}{ Dyke 1(TOA-96-6-7-1 and DS-00-3-2-5C) [baddeleyite] } \\
\hline A1 & 0.02 & 1397 & 275 & 3762 & 97 & 1.7 & $0.20779(0.09)$ & $2.3774(0.17)$ & $0.08298(0.09)$ & $1217.0(2.0)$ & $1268.8(3.4)$ \\
\hline A2 & 0.02 & 1389 & 271 & 1520 & 218 & 1.9 & $0.20540(0.10)$ & $2.3471(0.20)$ & $0.08288(0.12)$ & $1204.2(2.2)$ & $1266.3(4.8)$ \\
\hline A3 & 0.018 & 1177 & 234 & 2917 & 96 & 1.5 & $0.21024(0.10)$ & $2.4042(0.17)$ & $0.08294(0.09)$ & $1230.1(2.1)$ & $1267.8(3.6)$ \\
\hline A4 & 0.005 & 116 & 24 & 97 & 97 & 3.5 & $0.21431(0.39)$ & $2.4480(1.72)$ & $0.08284(1.48)$ & $1251.8(9.0)$ & $1265.5(57.8)$ \\
\hline A5 & 0.008 & 1768 & 219 & 2470 & 44 & 1.3 & $0.13140(0.18)$ & $1.5063(0.20)$ & $0.08314(0.07)$ & $795.8(2.7)$ & $1272.6(2.8)$ \\
\hline A6 & 0.005 & 4022 & 733 & 4451 & 50 & 1.3 & $0.19322(0.11)$ & $2.2121(0.13)$ & $0.08303(0.05)$ & $1138.8(2.3)$ & $1269.9(1.8)$ \\
\hline \multicolumn{12}{|c|}{ Dyke 2 (DT-95-1) [baddeleyite] } \\
\hline $\mathrm{B} 1$ & 0.005 & 685 & 132 & 1263 & 35 & 2.9 & $0.20170(0.07)$ & $2.2905(0.12)$ & $0.08236(0.09)$ & $1184.4(1.5)$ & $1254.1(3.4)$ \\
\hline B2 & 0.005 & 1500 & 297 & 1537 & 63 & 1.7 & $0.20618(1.5)$ & $2.3455(0.17)$ & $0.08251(0.08)$ & $1208.4(3.2)$ & $1257.6(3.3)$ \\
\hline \multicolumn{12}{|c|}{ Dyke 3 (JL-02-01) [zircon] } \\
\hline $\mathrm{C} 1$ & 0.02 & 1849 & 615 & 18790 & 26 & 39 & $0.21704(0.11)$ & $2.4778(0.12)$ & $0.08280(0.03)$ & $1266.2(2.6)$ & $1264.5(1.1)$ \\
\hline $\mathrm{C} 2$ & 0.025 & 2309 & 775 & 6872 & 110 & 40.5 & $0.21372(0.28)$ & $2.4412(0.29)$ & $0.08284(0.04)$ & $1248.6(6.3)$ & $1265.5(1.4)$ \\
\hline $\mathrm{C} 3$ & 0.019 & 2562 & 814 & 20420 & 31 & 36.9 & $0.21482(0.15)$ & $2.4516(0.16)$ & $0.08277(0.03)$ & $1254.4(3.2)$ & $1263.8(1.1)$ \\
\hline $\mathrm{C} 4$ & 0.029 & 3134 & 1025 & 8490 & 142 & 39 & $0.21364(0.48)$ & $2.4395(0.51)$ & $0.08282(0.11)$ & $1248.2(10.9)$ & $1264.9(4.3)$ \\
\hline C5 & 0.027 & 2170 & 657 & 12040 & 65 & 33.7 & $0.21503(0.18)$ & $2.4594(0.23)$ & $0.08295(0.09)$ & $1255.6(4.0)$ & $1268.1(3.7)$ \\
\hline C6 & 0.017 & 3707 & 1087 & 9588 & 85 & 33.5 & $0.20889(0.44)$ & $2.3807(0.47)$ & $0.08266(0.10)$ & $1222.9(9.8)$ & $1261.2(4.1)$ \\
\hline
\end{tabular}

${ }^{a} \mathrm{~N} 2, \mathrm{M} 2$ = non-magnetic, magnetic at indicated number of degrees side slope on Frantz isodynamic magnetic separator; grain size given in microns.

b Radiogenic $\mathrm{Pb}$; corrected for blank, initial common $\mathrm{Pb}$ (from Stacey and Kramer, 1975), and spike.

c Corrected for spike and fractionation.

d Corrected for blank $\mathrm{Pb}$ and $\mathrm{U}$, and common $\mathrm{Pb}$

e Decay constants from Steiger and Jäger (1977); errors assigned using the numerical error propagation method of Roddick (1987). 
fractions were analyzed (Table 2). The analyses form a linear array (Fig. 7b), and a Davis-type regression of all six analyses yields calculated upper and lower intercept ages of $1264.6 \pm 1.2 \mathrm{Ma}$ and $15 \mathrm{Ma}$, respectively, with a probability of fit of $45.5 \%$. The upper intercept gives the crystallization age of the diorite body and the lower intercept is consistent with mainly recent $\mathrm{Pb}$-loss from the zircons.

\section{Correlations with the Mackenzie igneous event}

Identical ages (within analytical uncertainty) of the BRD and the Mackenzie dyke swarm make inclusion of the BRD in the Mackenzie igneous event highly attractive. U-Pb ages of $1267 \pm 2$ Ma for 4 Mackenzie dykes, and $1270 \pm 4 \mathrm{Ma}$ for two Muskox intrusion samples were reported by LeCheminant and Heaman (1989), and supplant previous, younger K-Ar and $\mathrm{Rb}-\mathrm{Sr}$ ages for the Mackenzie event. As suggested by the tight age constraints, and supported by the radiating pattern and flow paths of the dyke swarm (Ernst and Baragar, 1992), Mackenzie-age magmatism is considered to have taken place in a very short interval, perhaps no more than 2 or 3 million years (LeCheminant and Heaman, 1989). The enormity of the Mackenzie event clearly points to the BRD as disparate members of the Mackenzie swarm.

Petrography and geochemistry support the inclusion of the BRD in the Mackenzie igneous event. The Coppermine River basalts generally consist of microphenocrysts of plagioclase and augite with accessory Fe-oxides in an interstitial groundmass of potassium feldspar and quartz (Baragar et al., 1996). The Mackenzie dykes have a similar mineralogy consisting essentially of plagioclase, pyroxenes and $\mathrm{Fe}-\mathrm{Ti}$ oxides, with quartz, potassium feldspar \pm biotite and amphibole in the interstices (Baragar et al., 1996). These assemblages are similar to the plagioclaseaugite-magnetite-granophyre \pm biotite mineralogy of the BRD.

Geochemically, the Coppermine River basalts and Mackenzie dykes are mostly quartz tholeiites (Dostal et al., 1983; Griselin et al., 1997), and share similar trace element profiles with the BRD (Fig. 5). The trace element patterns of the BRD are most similar to those of the Mackenzie dykes sampled between 400 and $500 \mathrm{~km}$ from the proposed focal point of the swarm (the BRD are located $\sim 1100 \mathrm{~km}$ from the focal point), and basalts in the lower part of the Coppermine River Group (Copper Creek Formation; Fig. 1). Striking $\mathrm{Pb}$-anomalies (positive) and $\mathrm{Sr}$-anomalies (negative) are shared by the BRD and the Copper Creek Formation. Initial $\varepsilon_{\mathrm{Nd}}$ values of the Mackenzie dykes and Coppermine lavas range from +4.9 to -9.8 (Dupuy and Dostal, 1992; Dudás and Peterson, 1992; Griselin et al., 1997), encompassing those of the BRD $(+1.2$ to -7.2). The range in $\varepsilon_{\mathrm{Nd}(T)}$ of the BRD is similar to the +1.7 to -5.5 range of the lower Coppermine River basalts (Griselin et al., 1997).

Crustal assimilation as a significant influence on the composition of the Coppermine lavas and Mackenzie dykes has been proposed on the basis of major and trace element abundances and $\mathrm{Nd}$ isotope geochemistry (Dudás and Peterson, 1992; Dupuy and Dostal, 1992; Dostal et al., 1983; Francis, 1994; Baragar et al., 1996; Griselin et al., 1997). Dykes and flows with strongly negative values of $\varepsilon_{\mathrm{Nd}(T)}$ are considered to have undergone significant crustal contamination, a process evident in an individual Mackenzie dyke with $\varepsilon_{\mathrm{Nd}(T)}$ values ranging from -0.6 in the interior of the dyke to -9.8 at the margin (Dudás and Peterson, 1992). However, details on the assimilation process remain uncertain because the more primitive igneous units commonly appear to have undergone a greater degree of crustal contamination than associated, less primitive ones (Dupuy and Dostal, 1992; Francis, 1994; Griselin et al., 1997). This notable trend of a decreasing "crustal" signature in more fractionated rocks is also evident in the BRD (Fig. 6).

\section{Regional significance}

The BRD, as correlative intrusions of the Mackenzie dyke swarm, provide key evidence that the Mackenzie igneous event was much more widespread than previously recognized. The BRD are the only dykes west of the Canadian Shield that have been correlated with the Mackenzie swarm, although numerous additional dykes may exist in the subsurface of western Canada, lying undetected beneath the extensive post-1.27 Ga sedimentary cover. In northern Yukon, the Proterozoic inliers which host the BRD provide a rare opportunity to evaluate the possible westward continuation of Mackenzie-age igneous rocks. 
If the BRD belong to the Mackenzie dyke swarm they should strike northeast, according to the model of radiating dyke propagation from a focal point on Victoria Island (Ernst and Baragar, 1992; Fig. 1). None of the BRD strike in the expected direction, and instead strike north to northwest. However, this lack of concordance does not preclude correlation with the Mackenzie swarm. Post-Mackenzie tectonic events in the Cordilleran orogen, ranging in age from Mesoproterozoic to Tertiary, comprise contractional, extensional and strike-slip deformation of different ages (Fig. 4). Folds and faults representing all of these deformational styles are recorded in the vicinity of the BRD (Thorkelson, 2000). These events may have reoriented the BRD from positions that were originally concordant with the expected trend of the Mackenzie dyke swarm.

Alternatively, the BRD may not have been reoriented, but instead may have been influenced by a local stress regime whose minimum compressive stress was oriented northeast rather than the northwest direction predicted by the radiating dyke model. In this hypothesis, magma would have flowed outward from the vicinity of the focal point, following a radially controlled pattern of tension. Upon reaching the area of northern Yukon, the magma would have encountered a different stress regime and begun flowing northwestward. Two explanations for such a local stress field in the Yukon area are tendered. In one, the stress field may have belonged to a concentric pattern of tension (relative to the focal point) as suggested by some dyke-like features on Mars (Montesi, 2001). The absence of a concentric pattern of Mackenzie dykes in other parts of Canada, however, casts doubt on this idea. In the other explanation, the local stress field may have been related to recurring episodes of extensional tectonism and basin formation in the Yukon region (Fig. 4). In general support of the local stress-field option, we note that at least one Mackenzie dyke, located $\sim 1000 \mathrm{~km}$ away from the focal point of the swarm, has a trend perpendicular to the main trend of the swarm (Pehrsson et al., 1993). These authors speculated that the dyke orientation may have been controlled by the similar-trending Great Slave Lake shear zone in the Slave craton or that the trend of the dyke may have been influenced by the local stress field at the time of emplacement. Similarly, Ernst et al. (1995b) suggested that the transition from a radiating pattern to one of parallel dykes at the southeastern extremity of swarm (Fig. 1) occurred because the dykes in that area extended beyond the region dominated by plume-generated updoming.

Evidence for additional Mackenzie-age magmatism in the subsurface of northern Yukon is implied by a $1.27 \pm 0.04 \mathrm{Ga} \mathrm{U}-\mathrm{Pb}$ monazite date from a hematitic breccia zone at the Nor mineral occurrence (Parrish and Bell, 1987). This breccia zone, which is exposed in a small inlier $150 \mathrm{~km}$ north-northwest of the BRD (Fig. 1), has been correlated with the $1.60 \mathrm{Ga}$ Wernecke Breccias (Figs. 2 and 4). The ca. $1.27 \mathrm{Ga}$ monazite age was originally regarded as the age of breccia emplacement (Parrish and Bell, 1987) but is now regarded as a product of secondary hydrothermal fluid activity (Thorkelson et al., 2001b). This Mackenzie-age hydrothermal pulse may have been driven by crustal heating in response to local BRD magmatism. How far the BRD extend beyond their area of exposure, hidden beneath sedimentary cover, is unknown, but their presence in the vicinity of the Nor breccia is plausible. An earlier hydrothermal fluid event in other Wernecke Breccias, recorded by ca. $1.38 \mathrm{Ga} \mathrm{U}-\mathrm{Pb}$ ages on rutile, has been linked to the nearby $1.38 \mathrm{Ga}$ Hart River sills (Abbott, 1997; Thorkelson et al., 2001b). The hypothesis of hydrothermal activity related to Mackenzie-age magmatism is similar to the suggestion of Davis (1997) who explained $1.27 \mathrm{Ga}$ thermal metamorphism in xenoliths from the subsurface of the western Canadian Shield (Fig. 1) by the presence of voluminous Mackenzie-age intrusions at depth.

The Tweed Lake basalts in the western Northwest Territories (Fig. 1) were previously regarded as the westernmost expression of Mackenzie magmatism. However, if the BRD are indeed Mackenzie dykes, as we suggest, then the extent of the Mackenzie swarm, in terms of both the angle of dyke radiation and the areal extent of magmatism, is significantly larger than previously recognized. Furthermore, if hydrothermal mineralization in the Nor breccia is accepted as a proxy for nearby Mackenzie-age intrusions, then the size of the Mackenzie igneous province is greater still. By using the Nor breccia as the western limit of Mackenzie dyking, the arc of the known swarm increases from $100^{\circ}$ to a remarkable $150^{\circ}$.

The identification of disparate members of the Mackenzie dyke swarm in Yukon is important for two 
main reasons. First, it broadly supports the prediction by Ernst and Baragar (1992) and Ernst et al. (1995a) that the Mackenzie swarm extended outward from the Canadian Arctic across much of ancestral North America (Laurentia). Second, the extension of the dyke swarm into western Canada means that other continents which may have lain alongside western Laurentia in Middle Proterozoic or later times, and were subsequently rifted away, may contain distal members of the Mackenzie swarm. Candidates for formerly attached continents include Australia (Bell and Jefferson, 1987; Moores, 1991; Ross et al., 1992), Siberia (Sears and Price, 2000), and South China (Li et al., 1995). If Mackenzie-aged dykes were to be identified in one or more of these regions, the orientation, composition, and exact age of the dykes would serve as valuable tools in resolving the controversy over paleocontinental reconstructions and understanding magmatic processes of giant dyke swarms.

\section{Acknowledgements}

Funding was provided by LITHOPROBE grants to D.J.T., NSERC grants to D.J.T., J.K.M., and R.A.C., an NSTP grant to D.L.S., and the Yukon Geology Program. The Radiogenic Isotope Facility at the University of Alberta is supported, in part, by an NSERC MFA grant. John Laughton helped with sample collection. This paper is a contribution to the International Geological Correlation Program, Projects 400 and 440, and to Lithoprobe (contribution no. 1356).

\section{References}

Abbott, J.G., 1997. Geology of the upper Hart River Area, Eastern Ogilvie Mountains, Yukon Territory (116A/10, 116A/11). Exploration and Geological Services Division, Yukon, Indian and Northern Affairs Canada, Bulletin 9, 76 p.

Aitken, J.D., Cook, D.G., Yorath, C.J., 1982. Upper Ramparts River (106G) and Sans Sault Rapids (106H) map areas. District of Mackenzie. Geological Survey of Canada, Memoir 388, 48 pp.

Baragar, W.R.A., 1969. The geochemistry of Coppermine River basalts. Geological Survey of Canada, Paper 69-44, 43 pp.

Baragar, W.R.A., Ernst, R.E., Hulbert, L., Peterson, T., 1996. Longitudinal petrochemical variation in the Mackenzie dyke swarm, northwestern Canadian Shield. J. Petrol. 37, 317-359.

Bell, R.T., Jefferson, C.W., 1987. A hypothesis for an AustralianCanadian connection in the late Proterozoic and the birth of the Pacific Ocean. In: Pacific Rim Congress '87, Parkville, Victoria, pp. 39-50.

Blusson, S.L., 1974. Geology of Nadaleen River, Lansing, Niddery Lake, Bonnet Plume Lake, and Mount Eduni map areas: Yukon Territory. Geological Survey of Canada, Open File 205, 1:250,000 scale.

Brideau, M.A., Thorkelson, D.J., Godin, L., Laughton, J.R., 2002. Paleoproterozoic deformation of the Racklan orogeny, Slats Creek (106D/16) and Fairchild Lake (106C/13) map areas, Wernecke Mountains, Yukon. In: Emond, D.S., Weston, L.H., Lewis, L.L. (Eds.), Yukon Exploration and Geology 2001. Exploration and Geological Services Division, Yukon Region, Indian and Northern Affairs Canada, pp. 65-72.

Campbell, I.H., Griffiths, R.W., 1990. Implications of mantle plume structure for the evolution of flood basalts. Earth Planet. Sci. Lett. 99, 79-93.

Cecile, M.P., 1982. The lower Paleozoic Misty Creek Embayment, Selwyn Basin, Yukon and Northwest Territories. Geological Survey of Canada, Bulletin 335, 78 pp.

Cecile, M.P., 1984. Evidence against large-scale strike-slip separation of Paleozoic strata along the Richardson-Hess fault system, northern Canadian Cordillera. Geology 12, 403-407.

Davis, W.J., 1997. U-Pb zircon and rutile ages from granulite xenoliths in the Slave province: evidence for mafic magmatism in the lower crust coincident with Proterozoic dike swarms. Geology 25, 343-346.

Dostal, J., Baragar, W.R.A., Dupuy, C., 1983. Geochemistry and petrogenesis of basaltic rocks from Coppermine River area, Northwest Territories. Can. J. Earth Sci. 20, 684-698.

Dudás, F.O., Peterson, T.D., 1992. Nd isotopic composition of Mackenzie Dikes, Northwest Territories, Canada (Abstract). AGU 1992 spring meeting. EOS, Transactions 73-14, American Geophysical Union, 339 pp.

Dupuy, C., Dostal, J., 1992. Proterozoic flood basalts from the Coppermine River area, Northwest Territories isotope and trace element geochemistry. Can. J. Earth Sci. 29, 1937-1943.

Eisbacher, G.H., 1981. Sedimentary tectonics and glacial record in the Windermere Supergroup, Mackenzie Mountains, northwestern Canada. Geological Survey of Canada, Paper 8027, $40 \mathrm{pp}$.

Ernst, R.E., Baragar, W.R.A., 1992. Evidence from magnetic fabric for the flow pattern of magma in the Mackenzie giant radiating dyke swarm. Nature 356, 511-513.

Ernst, R.E., Head, J.W., Parfitt, E., Grosfils, E., Wilson, E., 1995a. Giant radiating dyke swarms on Earth and Venus. Earth Planet. Sci. Lett. 39, 1-58.

Ernst, R.E., Buchan, K.L., Palmer, H.C., 1995b. Giant dyke swarms: characteristics distribution and geotectonic applications. In: Baer, G., Heimman, A. (Eds.), Physics and Chemistry of Dykes. Balkema, Rotterdam, Netherlands, pp. 3-21.

Fahrig, W.F., West, T.D., 1986. Diabase dyke swarms of the Canadian Shield. Geological Survey of Canada, Map 1627A.

Francis, D., 1994. Chemical interaction between picritic magmas and upper crust along margins of the Muskox Intrusion, Northwest Territories. Geological Survey of Canada, Paper 92$12,94 \mathrm{pp}$ 
Gibson, I.L., Sinha, M.N., Fahrig, W.F, 1987. The geochemistry of the Mackenzie dyke swarm, Canada. In: Halls, H.C., Fahrig, W.F. (Eds.), Mafic Dyke Swarms. Geological Association of Canada, Special Paper 34, pp. 109-121.

Griselin, M., Arndt, N.T., Baragar, W.R.A., 1997. Plumelithosphere interaction and crustal contamination during formation of Coppermine River basalts, Northwest Territories, Canada. Can. J. Earth Sci. 34, 958-975.

Heaman, L.M., 1997. Global mafic magmatism at 2.45 Ga: remnants of an ancient large igneous province? Geology 25, 299-302.

Hoffman, P., 1989. Precambrian Geology and tectonic history of North America. In: Bally, A.W., Palmer, A.R. (Eds.), The Geology of North America-An overview. Geological Society of America, Geology of North America, v. A., pp. 447-512.

Johnston, S.T., Thorkelson, D.J., 2000. Continental flood basalts: episodic magmatism above long-lived hotspots. Earth Planet. Sci. Lett. 175, 247-256.

LeCheminant, A.N., Heaman, L.M., 1989. Mackenzie igneous events, Canada: Middle Proterozoic hotspot magmatism associated with ocean opening. Earth Planet. Sci. Lett. 96, 3848.

Li, Z.-X., Zhang, L., Powell, C., 1995. South China in Rodinia: part of the missing link between Australia-east Antarctica and Laurentia? Geology 23, 407-410.

Montesi, L.G.J., 2001. Concentric dikes on the flanks of Pavonis Mons: Implications for the evolution of martian shield volcanoes and mantle plumes. In: Ernst, R.E., Buchan, K.L. (Eds.), Mantle Plumes: Their Identification Through Time. Geological Society of America Special Paper 352, pp. 165-181.

Moores, E.M., 1991. Southwest U.S.-East Antarctic (SWEAT) connection: a hypothesis. Geology 19, 425-428.

Mortensen, J.K., Ghosh, D., Ferri, F., 1995. U-Pb age constraints of intrusive rocks associated with copper-gold porphyry deposits in the Canadian Cordillera. In: Schroeter, T.G. (Ed.), Porphyry Deposits of the Northwestern Cordillera of North America. Canadian Institute of Mining and Metallurgy, Special Volume 46, pp. 142-158.

Norris, D.K., 1997. Chapter 3: Geological setting. In: Norris, D.K. (Ed.), The Geology, Mineral and Hydrocarbon Potential of Northern Yukon Territory and Northwestern District of Mackenzie. Geological Survey of Canada, Bulletin 422, pp. 21-64.

Norris, D.K., Dyke, L.D., 1997. Chapter 4: Proterozoic. In: Norris, D.K. (Ed.), The Geology, Mineral and Hydrocarbon Potential of Northern Yukon Territory and Northwestern District of Mackenzie. Geological Survey of Canada, Bulletin 422, pp. 65-84.

Parrish, R.R., Bell, R.T., 1987. Age of the Nor breccia pipe, Wernecke Supergroup, Yukon Territory. In: Radiogenic Age and Isotopic Studies. Report 1, Geological Survey of Canada, Paper 87-2, pp. 39-42.

Pehrsson, S.J., van Breeman, O., Hanmer, S., 1993. Ages of diabase dyke intrusions, Great Slave Lake shear zone, Northwest Territories. In: Radiogenic Age and Isotopic Studies. Report 7, Geological Survey of Canada, Paper 93-2, pp. 23-28.
Roddick, J.C., 1987. Generalized numerical error analysis with application to geochronology and thermodynamics. Geochim. Cosmochim. Acta 51, 2129-2135.

Ross, G.M., Parrish, R.R., Winston, D., 1992. Provenance and $\mathrm{U}-\mathrm{Pb}$ geochronology of the mesoproterozoic Belt Super Group (Northwestern United States): Implications for age of deposition and pre-Panthalassa plate reconstructions. Earth Planet. Sci. Lett. 113, 57-76.

Saunders, A.D., Storey, M., Kent, R.W., Norry, M.J., 1992. Consequences of plume-lithosphere interactions. In: Storey, B.C., Alabaster, T., Pankhurst, R.J. (Eds.), Magmatism and the Causes of Continental Break-Up. Geological Society Special Publication No. 68, pp. 41-60.

Sevigny, J.H., Cook, F.A., Clark, E.A., 1991. Geochemical signature and seismic stratigraphic setting of Coppermine basalts drilled beneath the Anderson Plains in Northwest Canada. Can. J. Earth Sci. 28, 184-194.

Schwab, D.L., Thorkelson, D.J., 2001. Geology and alteration signature of a Middle Proterozoic bear River dyke in the Slats Creek map area, Wernecke Mountains, Yukon (106D/16). In: Emond, D.S., Weston, L.H. (Eds.), Yukon Exploration and Geology 2000. Exploration and Geological Services Division, Yukon, Indian and Northern Affairs Canada, pp. 257266.

Schwab, D.L., 2001. Geology, geochemistry and regional implications of the Middle Proterozoic Bear River dykes, Wernecke Mountains, Yukon (106D/16, 106C/13). B.Sc. thesis, Simon Fraser University, Burnaby, Canada.

Sears, J.W., Price, R.A., 2000. New look at the Siberian connection: no SWEAT. Geology 28, 423-426.

Stacey, J.S., Kramer, J.D., 1975. Approximation of terrestrial lead isotope evolution by a two-stage model. Earth Planet. Sci. Lett. 26, 207-221.

Steiger, R.H., Jäger, E., 1977. Subcommission on geochronology: convention on the use of decay constants in geo- and cosmochronology. Earth Planet. Sci. Lett. 36, 359-362.

Sun, S., McDonough, W.F., 1989. Chemical and isotopic systematics of oceanic basalts: implications for mantle composition and processes. In: Norry, M.J. (Ed.), Magmatism in the Ocean Basins. Geological Society Special Publication 42, pp. 313-345.

Thorkelson, D.J., 2000. Geology and mineral occurrences of the Slats Creek, Fairchild Lake and "Dolores Creek" areas, Wernecke Mountains, Yukon Territory (106D/16, 106C/13, 106C/14). Exploration and Geological Services Division, Yukon, Indian and Northern Affairs Canada, Bulletin 10, $73 \mathrm{p}$.

Thorkelson, D.J., Mortensen, J.K., Creaser, R.A., Davidson, G.J., Abbott, J.G., 2001a. Early Proterozoic magmatism in Yukon, Canada: constraints on the evolution of northwestern Laurentia. Can. J. Earth Sci. 38, 1479-1494.

Thorkelson, D.J., Mortensen, J.K., Davidson, G.J., Creaser, R.A., Perez, W.A., Abbott, J.G., 2001b. Early Mesoproterozoic intrusive breccias in Yukon, Canada: the role of hydrothermal systems in reconstructions of North America and Australia. In: Bartley, J.K., Kah, L.C. (Eds.), Rodinia and the Mesoproterozoic Earth-Ocean system. Precambrian Research, vol. 111. Elsevier, Amsterdam, pp. 31-56. 